\title{
Framing Theoretical/Conceptual Frameworks and Research Processes in African Indigenous Knowledge Systems and Everyday Experiences
}

\author{
Felix Banda ${ }^{\mathrm{a}, *}$ and Dennis Banda ${ }^{\mathrm{b}, \boldsymbol{}}$ \\ ${ }^{\mathrm{a}}$ University of the Western Cape, South Africa \\ ${ }^{\mathrm{b}}$ University of Zambia, Zambia
}

\begin{abstract}
This article shows how indigenous knowledge systems and everyday experiences can be used to scaffold theoretical and analytical frameworks as well as to teach aspects of research processes and procedures in a non-intimidating way. We use everyday African experiences and proverbs to show that production of new knowledge does not have to be in English and associated exogenous culture; rather it will be more expedient and have lifelong impact on students if expressed in familiar language practices and knowledge systems. Eurocentric-based epistemologies and knowledge systems will only have profound meaning in Africa if framed in and expressed through local indigenous knowledge systems. We conclude that there is need for research protocols and theoretical/analytical frameworks to be filtered through African socio-cultural contexts and knowledge systems for comprehensive and culturally-relevant meaning making. This would dispel the current obsession with ritualized research, the mysticism associated with Eurocentric research, and perceptions that only formally-educated people are eligible to do research.
\end{abstract}

Keywords: Indigenous Knowledge Systems, Everyday Knowledge, Proverbs, Research, Theory, Africa, Higher Education

\section{Introduction}

Research is considered a sacred area reserved for the few in the academia world. That may explain why only few write on their Curriculum Vitae (CV) that they are researchers. In many African Universities, research is taught to only postgraduate students. The undergraduate students may take some courses with a semblance of "research" and are called long papers for fear that students would shun away from them if they were promoted as research courses. Research has acquired an air of mystic and it is promulgated as being difficult and requiring long hours of preparation and execution. Thus, students often choose to shun courses with a "research" label for fear of failing. Although the main goal of academic research relate to clarifying phenomena and/or extending knowledge, it is not uncommon for members of staff in the universities to do research for promotion purposes or renewal of their contracts. Otherwise they would not have anything to do with "research." This may explain, among other reasons, why the ranking of many African uni-

*Corresponding author email: fbanda@uwc.ac.za.

${ }^{\dagger}$ Corresponding author email: dennisnk@hotmail.com. versities in the world is poor as very little research takes place. Banda and Islam (2011) argue that the teaching of research using the Eurocentric models has contributed to the mystification of research. The Eurocentric approach to research is modelled on the formal domain in which activities take place often in institutionalized style. In this regard, Banda and Islam (2011: 4-5) observe that when it comes to conducting research in the South certain procedures and methods advocated in Eurocentric academia may prove problematic. For instance, interview questions may have to be a bit more indirect than advocated in Western-style research. Institutionalized direct questioning and statements such as "You are free not to be involved in this research" may be seen as offensive in African societies, whose underlying culture ad philosophy (of ubuntu or "belief in humanity") are based on helping others. Thus, such a statement may have to be rephrased in such a way that the interviewee's positive (involvement) face is preserved.

\section{Daily Practices and Experiences of People}

Banda and Islam (2011) argue that human beings are by nature researchers and that is regardless of their education status. The Nguni people running away from Shaka Zulu war of conquest in 
South Africa managed to reach their destinations thousands of kilometres away from Kwazulu Natal not by accident but through research. Research parties would be sent in advance of the group to collect data on the route they were to use, what kind of people they were to encounter and identify any obstacles they would meet. When a village is shifting to new places, advance parties are sent to collect data on various aspects ranging from fertility of the land where they are going, presence and reliability of water sources for themselves and their animals. In the case of looking for spouse for any member of the family, data collectors would be dispatched to various villages in search of a suitable lady or man and the information they would be interested in is the history of her or his parents. How hard working are they? Do they grow enough food for themselves or are they perpetual beggars? All these and many more pertinent issues will arise and will require research. If one follows the stages followed by these 'unlettered' men and women, one is amazed to find out that they also cover stages of the contemporary research proposal. Proverbs and other indigenous knowledge systems are tools that can be used to demystify research as well as to scaffold difficult theoretical and conceptual frameworks, as they are used by everyday people in their search for answers for various social problems they meet in life.

Following Banda's (2008) description of proverbs as knowledge "capsules" of wisdom, Banda and Banda (2016) argue that proverbs can be used to recontextualize knowledge for academic writing purposes. Using the typical two-part structure of proverbs, Banda and Banda (2016, p. 80) link this to systemic functional linguistics' Theme-Rheme structure, which relates to the "topic or thesis statement followed by logical argumentation for support or 'proof,' [which] is also the basic structure of the construction of academic discourse." It is not surprising that Kamanga (1996) has described proverbs as "libraries" of wisdom, norms and beliefs. Since they are not tied to time and space, proverbs are so versatile that they can be used in many contexts for different socio-cultural, political and even educational purposes. Similarly, proverbs as part of everyday knowledge are not tied to a particular topic, and as such could be used to scaffold and to relate the logic holding between theories and concepts in research or academic expositions.

Following Kamanga's (1996, p. 1) categorization of proverbs into three broad groupings - (1) judicial cases proverbs (Miyambi yoweluzila milandu); (2) character formation and for inculcating good morals proverbs (Miyambi ya mikhalidwe), and (3) miscellaneous purposes proverbs (Miyambi yosiyana-siyana) - Banda and Banda (2016) suggest that it is not uncommon for contemporaries or for an elderly person to use proverbs to give educational or life lessons to a younger person. The advantage of proverbs is that information is given and received in a non-face threatening way. It is in this same respect that proverbs can easily be used to frame what are otherwise "threatening" theoretical and conceptual frameworks in social science research. Using them to explain how theoretical and conceptual frameworks work could be better understood than the case is when such concepts are taught in abstract ways and using the decontextualized models from the North.

While in his study of Kinyarwanda proverbs, Kambanda (2004) concludes that proverbs can provide authentic teaching material on which African languages and former colonial languages such as French and English can be based, this paper, however, goes further to argue that proverbs and everyday knowledge can be used to frame and scaffold theories, concepts and the logics of the research design and procedure in a non-threatening locally relevant manner.

Moreover, the typical structure of proverbs constituted by two thematically related parts, "the beginning" and "the end" as discourse can be used to teach not only aspects of academic writing (Banda and Banda 2016) but also what constitutes the theoretical and conceptual frameworks in social research. Just like academics refer to other texts, the use of proverbs and everyday sayings as texts can exemplify how academics refer to other works, explicate theories and concepts, and to make logical arguments and to hold a study together. Using the structure and arguments in proverbs as explained above, learners can easily recognize the value of textual cohesion, guidance and coherence embedded in theoretical frameworks used in social science research (Banda and Banda 2016).

What this paper will demonstrate is that proverbs and everyday experiences, can be used to frame theoretical and conceptual frameworks as a way to embed them in familiar contexts. This is in addition to inculcating in learners the discipline of critical thinking, logical and thematic organization of information, which are important in the research process and procedure (Banda \& Banda 2016, 2017).

\section{Defining Indigenous Knowledge}

The problem of what constitutes indigenous knowledge (IKS) and local knowledge has been discussed by a number of researchers (Banda and Banda 2017; Banda 2008; Hoppers 2004; Jackson 2014). IKS has been defined differently by different academics. This has made the concept difficult to operationalize in research. However, we agree with Hoppers (2004) and others such as the ICSU Study Group (2002), which associates IKS with traditional knowledge. IKS is thus the sum total of knowledge that a community of speakers have acquired and over time (Banda and Banda 2016). It includes knowledge related to "language, naming, classification systems, resource use practices, ritual, spirituality and worldview" (ICSU Study Group 2002, p. 3). As Banda and Banda (2016) also note, IKS is about a people's know-how, norms and patterned interactions with others and their environment as passed on from one generation to another. The argument of this paper is 
that such practices can easily be used to frame theoretical and conceptual frameworks in research proposals and in writing actual reports, as this means moving from the known to the unknown (Banda and Banda 2016).

According to Banda and Banda (2017) indigenous knowledge and everyday knowledge are connected in that both can be transmitted from generation to generation, usually without formal instruction. Just like everyday knowledge is derived from everyday practices and life, indigenous knowledge also derives from knowledge transmitted through different social networks and communities of practice to which one belongs (Banda and Banda 2017). This paper defines those practices that indigenous people perform and follow as forming a particular community of practice. Thus, proverbs and other patterned behaviours and practices that people are involved are part of their IKS.

However, we are mindful that as knowledge is relocated across generations, successive generations do not automatically accept the knowledge passed on as a-given (Banda and Banda 2016). They engage with it and sometimes modify it to suit their current needs (cf. Hoppers 2004). Hoppers (2004, p. 2) differentiates between IKS linked to traditional knowledge, and cosmopolitan knowledge which is associated with Western cosmology, scientific discoveries, and economic preferences. Using the slots of IKS below one would hold that everyday people are in constant move in conducting research to try to understand and study their environment (see Figure 1).

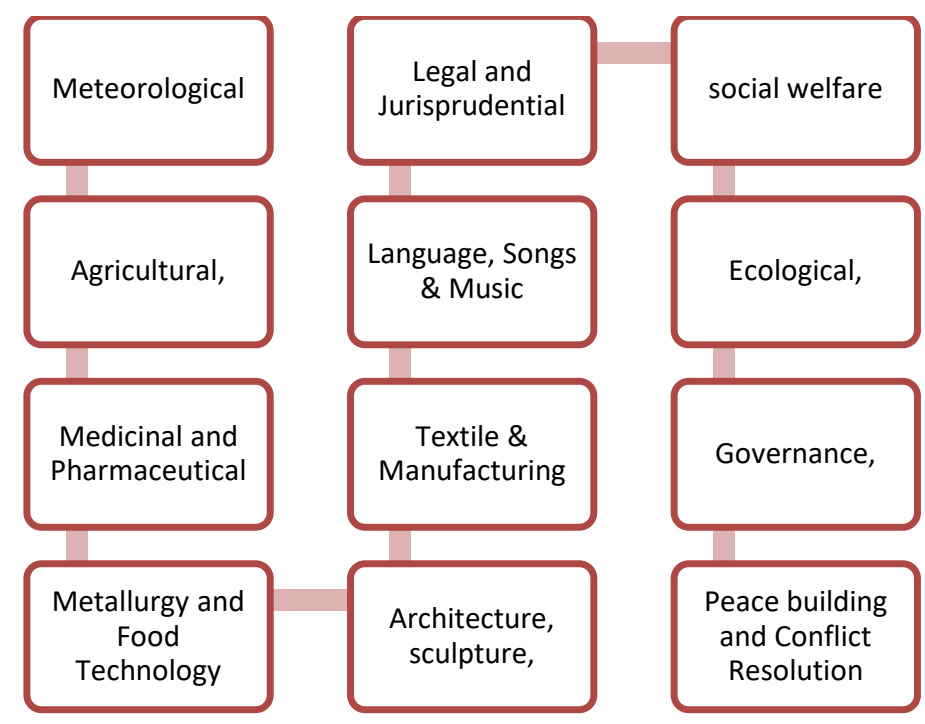

Figure 1. Slots for Indigenous Knowledge System

Source: Hopper (2004, p. 56).

Understanding such aspects would not only widen the scope on the relevance of IKS but also appreciate the notion that everyday people do get involved in research to understand their space in the wider environment and try to make meaning of what is going on around them. It therefore goes without saying that appreciation of the wider picture from which research agenda can be drawn can promote outcome-based research rather than the current trend where in many instances, research is conducted to secure a promotion at work rather than doing research to solve mankind's everyday problems (Banda and Banda 2016, 2017).

In their illustration of how scholarship of teaching and learning (SOTL) in the global South can give impetus to the construction of new and more powerful knowledge, Banda and Banda (2017) suggest dialogic rather than discontinuous pedagogy between everyday knowledge and formalized academic knowledge. Locating these slots in IKS will ensure that more powerful socio-economic pursuits in Africa, for example, are not the preserve of a colonial language such as English and epistemologies embedded in Western thought.

\section{Everyday Practices as Research Platform}

Banda and Banda (2017) have argued that one major downside to research and current education in Africa generally is that they are premised on formal aspects of Western education and Eurocentric research models as stated already in this paper. It is also the case that Africans may not be familiar with formal examples in English, French, Portuguese and other colonial languages when teaching research, but with examples in African languages, which they may speak very well. However, the problem is not just a language choice one: the school systems and research including epistemologies and/or ways of knowing in Africa have been structured in the image of Western education, research models and knowledge systems generally. This has implications for curriculum design and content, as well as models in planning and delivery and consumption (Banda and Banda 2017). In the majority of cases, research is not taught in primary or secondary schools but reserved for universities at postgraduate stage. What people do not ask themselves is that why is it that every day and "unlettered" people are able to investigate a number of social, economic, spiritual etc. and arrive at solutions that have made them survive their harsh environment for ages?

Below we demonstrate using every day people's experiences how such people are conducting research process and procedures without apparently knowing it or because the Eurocentric paradigm prevents us from recognizing it as research.

\section{Marketeers as Researchers}

Typical marketeers need to know how much produce to order as well as the quality to enable them generate reasonable profit margins. Let us consider the following example of a how marketeers can be said to be a researchers conducting full-fledged qualitative 
and quantitative research design: If marketeers were to pronounce themselves as researchers, would those in the academia who consider themselves as gate keepers of knowledge agree with such credentials and consider them valid? They would, for sure not. But the truth of the matter is they are. They need to find out what to sell, where to find the merchandise, how to transport it and still generate a comfortable profit margin. All the various measurement instruments the marketeers deploy are not by chance as they rely on data collected over time from various areas where the same items are sourced and sold (Banda and Banda 2017).

\section{Generating a Title}

The title gives an idea of what the paper is about. Marketeers have ideas about what products they want to source, and in what quantities and qualities.

\section{Background and Statement of the Problem}

Background information could include their experiences of the product or manufacturer of the product. It could also mean their experiences regarding the selling of the product. Does the product sell well? Will they make a profit? What is the shelf life of the product? All these could be triggered by her noticing a gap for a particular product more like how an academic notices a gap in literature or theory. It may also be due to noticing that the products being sold are running low and needed replenishing. This is more like a researcher trying to add to theories in place by doing more research.

\section{Research Objectives and Questions}

The marketeer needs to have clear objectives about why it is necessary to order more bags of potatoes, for example. They also need to come up with questions about whether they are the same or similar products being sold and how they will be able to sell them at profit. They may also want to find out what language to use in order to market their products more or less like a research trying to identify the kind of academic writing and jargon to use in a research.

\section{Literature Review and Theoretical Framework}

Having an idea about how others have experienced a particular product or related products is important. The marketeer's knowledge of the market situation, the product and what others have said about them provide the theoretical and analytical framing surrounding the decision, for example, about whether to go ahead to buy the product or go for a different product altogether. It is in this aspect that proverbs guiding their search could be used that could either encourage or discourage them to go ahead and order the products or be extra careful before they order as outside appearance of some products could be deceiving: Cikome-kome cankhuyu mkati muli nyelele (the appearance of a fig fruit could be deceiving as there could be ants in side).

In research, there are moments when one is not sure which method would give more and better data than the other resulting into triangulating various methods. In a similar manner, the marketeer woman may not limit her buying to one product only but may buy even those not planned for as she may not know for sure which product at the end of it all may prove to be what people really want. She may find solace and guidance from proverbs such as the one below and say, 'Let me also buy those products as the saying goes that Cinanenepetsa mnkhwele sicidziwika (let me also buy the other product in line with the proverb which says, "What really fattened a baboon is not known").

\section{Methodology, Limitations and Ethics}

It is important to know how the product will be sourced. Does one need a vehicle to go and collect the produce? What possible problems/limitations does the marketeer envisage in acquiring the produce? Does she have storage facilities? As for ethics, the marketeer needs to be aware of the dangers of selling expired products, counterfeit products or stolen property.

\section{Findings and Discussion}

These would relate to whether the product has been found or not, and in what quantity and quality. Some of the discussion will be with other marketeers regarding the product and with customers which may relate to pricing and quality of the product in question.

There is no doubt that if a marketeer was to introduce herself as a researcher, many in the academia would shake their heads in disapproval. The main reason why many in academia would not consider the woman to be a researcher is when they consider the stages religiously followed in conducting and writing research. The arguments they may possibly give could be based on their own experiences with students doing research as post-graduate students. Some have failed their dissertation and thesis writing because they collected wrong data or because of using wrong instruments. In some cases the research title is not clear and not even outcome based. It could also be that the background information is answering the research questions suggesting that the research paper can end at background information stage. There are also cases where the theoretical framework is not holding the study at all. The other commmon problem is where the literature review is not informing the study or answering the research question. Thus, it has not been 
carefully thought through, so as to identify clear research gaps. Challenges involving stages such as the presentation of findings are also many and notable ones are where the presentation of findings is jumbled up as one reviews literature instead. It could also be that the findings presented are not related to the data or theories being used.

Below we illustrate further how everyday experiences and proverbs can be used to scaffold theoretical and conceptual frameworks. We use the experience of a woman as she tries to find answers to her social problem at home.

\section{Framing Research Processes In and Through Everyday Social Knowledge}

Let us suppose a woman is looking for answers to problems in her family involving her husband. This is an example we have used in class when teaching our postgraduate students and has worked very well.

\section{Research Title, Background Information, Statement of the Problem and Significance of Study}

Assuming the situation as described above, the woman needs to be familiar with background information, which she uses to formulate the problem at hand.

\begin{tabular}{|c|c|c|c|}
\hline Experience & Action Taken & $\begin{array}{l}\text { Stage from the Generative } \\
\text { Research Proposal Covered }\end{array}$ & $\begin{array}{l}\text { Example of Process Taken Similar to Known } \\
\text { Resarch Process }\end{array}$ \\
\hline $\begin{array}{l}\text { 1. She may notice that her husband } \\
\text { comes late everynight and is } \\
\text { abusive each time she asks him } \\
\text { where he had been. He sometimes } \\
\text { scolds her for no apparent reason. }\end{array}$ & $\begin{array}{l}\text { She may want to find out } \\
\text { why he is behaving that } \\
\text { way and may want to } \\
\text { establish if he has another } \\
\text { woman or not. }\end{array}$ & A research title & $\begin{array}{l}\text { Research title: An inverstigation into whether or } \\
\text { not the husband has another woman. }\end{array}$ \\
\hline $\begin{array}{l}\text { 2. If you asked her what the } \\
\text { problem she has and why she wants } \\
\text { to carry our some investigation. }\end{array}$ & $\begin{array}{l}\text { She will give a story which } \\
\text { gives a clear background to } \\
\text { the problem. }\end{array}$ & Background information & $\begin{array}{l}\text { I got married to this man in } 1972 \text {. We have four } \\
\text { children now. He has been a very good husband } \\
\text { and father until recently. Suddenly he comes } \\
\text { home late everyday, smelling of some strange } \\
\text { perfumes. I want to find out if he has another } \\
\text { woman or not. }\end{array}$ \\
\hline $\begin{array}{l}\text { 3. People may want her to state the } \\
\text { reall problem she has so that they } \\
\text { follow the story properly. }\end{array}$ & $\begin{array}{l}\text { She may give a clear } \\
\text { statement that states the } \\
\text { problem. }\end{array}$ & Statement of the problem & I want to find out if he has found another woman. \\
\hline $\begin{array}{l}4 \text {.If asked as to why she is doing } \\
\text { an investigation on her husband, } \\
\text { she may find ways to justify the } \\
\text { move taken. }\end{array}$ & $\begin{array}{l}\text { She may explain and justify } \\
\text { the action taken. }\end{array}$ & Significance of the study & $\begin{array}{l}\text { She may say, "I want to establish the truth about } \\
\text { his movements so that we save our marriage and } \\
\text { look after our children together, as that way we } \\
\text { may prevent a divorce." }\end{array}$ \\
\hline
\end{tabular}




\section{Objectives, Research Questions, Theoretical and Conceptual \\ Frameworks}

She needs to formulate clear objectives and questions to help her carry out the objectives. And she may need to come up with hypothesis, concepts, and theory to help her understand what is happening as illustrated below.

\begin{tabular}{|c|c|c|c|}
\hline Experience & Action Taken & $\begin{array}{l}\text { Stage from the Generative } \\
\text { Research Proposal Covered }\end{array}$ & $\begin{array}{l}\text { Example of Process Taken Similar to Known } \\
\text { Resarch Process }\end{array}$ \\
\hline $\begin{array}{l}\text { 5. People may want her to state } \\
\text { clearly things she wants to find out. }\end{array}$ & $\begin{array}{l}\text { She may state three or so } \\
\text { things puzzling her about } \\
\text { the new behaviour of her } \\
\text { husband. }\end{array}$ & $\begin{array}{l}\text { Objectives of her } \\
\text { investigation }\end{array}$ & $\begin{array}{l}\text { a). To extablish why he comes late everyday. } \\
\text { b). To establish why he carries his phone each } \\
\text { time he goes to the toilet or bathroom. } \\
\text { c). To explore possible reasons why he has } \\
\text { suddenly put a password on his phone. } \\
\text { d). To establish reasons why he does not allow } \\
\text { her to wash his clothes before a thorough check } \\
\text { for documents in his pockets. } \\
\text { e). To try to call him while he is in the toilet to } \\
\text { establish how many times the phone is engaged. } \\
\text { f). To explore from the neighbours if they have } \\
\text { any idea where the man goes. }\end{array}$ \\
\hline $\begin{array}{l}\text { 6. If asked to state the questions she } \\
\text { intends to ask various people over } \\
\text { what she is going through, she may } \\
\text { give questions }\end{array}$ & $\begin{array}{l}\text { She is likely going to give } \\
\text { questions equal to the } \\
\text { objectives she has set for } \\
\text { herself }\end{array}$ & $\begin{array}{l}\text { Research questions which } \\
\text { may mirror the objectives set }\end{array}$ & $\begin{array}{l}\text { a). Why does he come late every night? } \\
\text { b). Why does he carry his phone when going to } \\
\text { the toilet and bathroom? } \\
\text { c). Why has he suddenly put a password on the } \\
\text { phone? } \\
\text { d). What kind of documents does he keep in his } \\
\text { pockets which he has become so sensitive with? } \\
\text { e). How many times is his phone engaed when he } \\
\text { is in the toilet suggesting he is calling other } \\
\text { people? } \\
\text { f). What information could neighbours arround } \\
\text { have about his behaviour? }\end{array}$ \\
\hline $\begin{array}{l}\text { When trying to support her } \\
\text { argument, she may use some long- } \\
\text { established sayings that seem to } \\
\text { give a frame to her problems. }\end{array}$ & $\begin{array}{l}\text { She is likely going to use } \\
\text { proverbs and sayings of the } \\
\text { wise to either justify what } \\
\text { she is doing or predict what } \\
\text { may happen }\end{array}$ & $\begin{array}{l}\text { Theoretical and conceptual } \\
\text { frameworks }\end{array}$ & $\begin{array}{l}\text { The following proverbs may be used to give her a } \\
\text { frame or direction: } \\
\text { a). Wakhungu akati nikutema, waponda mwala } \\
\text { (When a blind person says I will stone you, he } \\
\text { must be stepping on a stone). } \\
\text { b). Pali utsi pali moto (There is no smoke without } \\
\text { fire). }\end{array}$ \\
\hline
\end{tabular}

\section{Methodology, Limitations and Ethical Issues}

There is need for the woman to be familiar with various ways of investigating and gathering information regarding such a social problem. She also needs to be aware of the social and cultural boundaries regarding what her rights are and the fact that others also have social and cultural prerogatives. She should also avoid prejudging the outcome (including pointing accusing fingers at other women before she has gathered evidence). She also needs to be wary of who to approach for information and the kinds of 
questions to ask. It is not advisable to include children as part of your sample in such a topic. She may not discuss her problems in the presence of visitors. Research institutions and higher education institutions have ethics committees that scrutinise research proposal before researchers embark on research for possible ethics breaches. To prevent possible abuse of children's rights not to be interviewed if they so wish, and to prevent children from psychological or physical harm resulting from research endevours, ethics committees are very strict with research that involves minors. It is also the case that participants in a research are asked to sign a form that parts of the interview would not be divulged, the same underking is usually expected of the researcher not to disclose the identities of participants.

\begin{tabular}{|c|c|c|c|}
\hline Experience & Action Taken & $\begin{array}{l}\text { Stage from the Generative } \\
\text { Research Proposal Covered }\end{array}$ & $\begin{array}{l}\text { Example of Process Taken Similar to Known } \\
\text { Resarch Process }\end{array}$ \\
\hline $\begin{array}{l}\text { 7. She wants to adopt ways in } \\
\text { which she wants to find out or } \\
\text { collect information. }\end{array}$ & $\begin{array}{l}\text { The questions she has set } \\
\text { for herself in } 6 \text { will give her } \\
\text { the methodology and } \\
\text { methods to be used }\end{array}$ & $\begin{array}{l}\text { Methodology and methods. } \\
\text { The use of testing and other } \\
\text { stated methods shows that the } \\
\text { lady has used a qualitative } \\
\text { and quantitative research } \\
\text { methods and has used } \\
\text { triangulation for better } \\
\text { results. }\end{array}$ & $\begin{array}{l}\text { a). Asking him why he comes late = Interviews. } \\
\text { b). Phoning him when he is in the toilet with his } \\
\text { phone to see how many times the phone is busy = } \\
\text { Testing. } \\
\text { c). Checking what he hides in his pockets which } \\
\text { makes him empty them before they are } \\
\text { surrendered for washing = Document analysis. } \\
\text { d). Asking neighbours what they may know about } \\
\text { him = Focus group discussions. Not all } \\
\text { neighbours can be targeted for this discussion but } \\
\text { only those who seem to have rich informtion on } \\
\text { the problem = Purposeful sampling. She may be } \\
\text { told to ask another person at the next village = } \\
\text { snowball sampling. As she is going to that } \\
\text { village, she may meet some people on the way } \\
\text { and feel like asking them just in case they may } \\
\text { have some informatgion = random sampling. }\end{array}$ \\
\hline $\begin{array}{l}\text { 8. What else can be used to inform } \\
\text { the problem she is investigating } \\
\text { which can also be used to inform } \\
\text { the case at hand? }\end{array}$ & $\begin{array}{l}\text { In the African context, } \\
\text { songs are like "story } \\
\text { books". They are oral } \\
\text { literature that are highly } \\
\text { contextual. Listen to the } \\
\text { songs she will be playing } \\
\text { during those trying } \\
\text { moments. They will be } \\
\text { songs with themes similar } \\
\text { to the problems she is } \\
\text { experiencing. }\end{array}$ & Literacture review & $\begin{array}{l}\text { They will be songs that hint on men behaving } \\
\text { badly or very well towards their wives and } \\
\text { family. She is likely to be selective in her choice } \\
\text { of songs and not sing songs that glorify men } \\
\text { abusive behaviour towards women. However, she } \\
\text { may not play so much those songs indicating a } \\
\text { divorce or separation as that would be using } \\
\text { literature review to answer your research topic } \\
\text { before the data/information has been analysed. } \\
\text { This is also like predicting the outcome before the } \\
\text { study is done. }\end{array}$ \\
\hline $\begin{array}{l}\text { 9. When asked where else she will } \\
\text { go to carry out her investigation, } \\
\text { where would she not propose? }\end{array}$ & $\begin{array}{l}\text { She is likely going to limit } \\
\text { the study area to the } \\
\text { locality near her home and } \\
\text { not to villages far away } \\
\text { from her }\end{array}$ & Delimitations & $\begin{array}{l}\text { It may not make sense for her to cover a radius of } \\
200 \mathrm{kms} \text { trying to find out why her husbad comes } \\
\text { late in the night everyday. She would surely limit } \\
\text { her investigation within a meaningful distance }\end{array}$ \\
\hline $\begin{array}{l}\text { 10. If visitors arrived at their home, } \\
\text { would she tell them what is going } \\
\text { on? Does she disclose the problem } \\
\text { to children? }\end{array}$ & $\begin{array}{l}\text { Chances are that she would } \\
\text { not share with visitors what } \\
\text { she is trying to carry out let } \\
\text { alone disclosing to them } \\
\text { her suspicions. }\end{array}$ & Ethical issues & $\begin{array}{l}\text { If there were not in talking terms during the } \\
\text { visitations, the silence would be broken } \\
\text { immediately so that vistors are not aware of the } \\
\text { problems in the house. }\end{array}$ \\
\hline
\end{tabular}




\section{Findings, Discussion and Dissemination}

In a rural village setting she may be asked to present her case and findings to a group of elders or traditional court. It may also be to a group of selected family members from both sides. With urbanisation, this may be presented at local court dedicated to such matters.

\begin{tabular}{|c|c|c|c|}
\hline Experience & Action Taken & $\begin{array}{l}\text { Stage from the Generative } \\
\text { Research Proposal Covered }\end{array}$ & $\begin{array}{l}\text { Example of Process Taken Similar to Known } \\
\text { Resarch Process }\end{array}$ \\
\hline $\begin{array}{l}\text { 12. After narrating her stories, the } \\
\text { gathering may want to discuss } \\
\text { issues presented one by one. }\end{array}$ & $\begin{array}{l}\text { They follow each finding } \\
\text { and discuss and establish its } \\
\text { merit or demerit it before } \\
\text { moving to the other. }\end{array}$ & Discussion of findings & $\begin{array}{l}\text { If a given finding lacks merit it may be } \\
\text { disqualified right there and then. For example if } \\
\text { the document analysis brought out issues of the } \\
\text { man having condoms in his pockets when they } \\
\text { don't use any in the house, the man cannot come } \\
\text { up with ways of jusfying the presence of such } \\
\text { commodities e.g sugggesting that he uses them to } \\
\text { tie the valves for his bicycle tubes. }\end{array}$ \\
\hline $\begin{array}{l}\text { 13.After all the discussions, } \\
\text { resolutions and decisions are made. } \\
\text { Reommendations may also be } \\
\text { brought forward . In the case of } \\
\text { some matrilineal African } \\
\text { communities such as the Nsenga } \\
\text { and Chewa found in Southern } \\
\text { Africa, where a man goes to live in } \\
\text { the wife's village, discussions } \\
\text { involving marital problems are } \\
\text { convened in the morning to give } \\
\text { chance for the man to pack his } \\
\text { things and go to his village in an } \\
\text { event that the marriage has ended. }\end{array}$ & $\begin{array}{l}\text { If the marriage has ended, } \\
\text { and depending on the } \\
\text { manner of ending, the man } \\
\text { can be denounced in songs } \\
\text { composed by some } \\
\text { observers. }\end{array}$ & $\begin{array}{l}\text { Publication and } \\
\text { dissemination }\end{array}$ & $\begin{array}{l}\text { Sometimes more data is released on the man's } \\
\text { failures in managing his home. That kind of news } \\
\text { spreads rapidly so that it acts as a warning to } \\
\text { others or act as a warning to some who may be } \\
\text { fooled into wanti to marry this same man. }\end{array}$ \\
\hline
\end{tabular}

\section{Conclusion}

In this paper we have shown how everyday experiences are embedded and constitute indigenous knowledge systems that not only mirror but can be used to teach aspects of the research processes and procedures in a non-threatening and less mystified way. This would be particularly useful as it draws on learners' everyday experiences, lifestyles or issues and people they know (Banda and Banda 2017). Just like experiences and lifestyles are not fixed and static, the model described above can be modified to suit 
different research problems and topics in pursuit of knowledge. Jackson (2014, p. 136) highlights that IKS should not be viewed as permanent or a reproduction of the past, but as "a dynamic within a cultural interface that constantly produces new knowledge and social forms ... albeit through geopolitical power dynamics that have a profound effect on this production." The two examples show how ordinary people's socio-cultural expereiences can be drawn to scaffold theorectial and conceptual frameworks, as well as to make the research processes and procedures less tedious and "foreign." Further, we argue that demystification of research by using people's everyday experiences and practices within their community of practice should be encouraged. We are mindful that the global and local dynamics are increasingly becoming inextricably entangled. Thus, it can be said that it is not always possible to disassemble global and indigenous knowledge systems. We find nothing wrong with such a situation as long as such a hybrid aggregation is geared towards and is recognised as localised knowledge system. The problem is when the global or Eurocentric knowledge systems are at odds or seat in, unequal power relations and suppress the local and indigenous systems (Banda and Banda 2017). This works to disadvantage local people in their pursuit of knowledge as their ways of finding solutions to problems are shot down as unworkable or "unscientific." Our argument is that conducting research in IKS should not just be about unveiling and making transparent the "global-local dynamic driven by power relations that seek to impose a dominant view" that marginalises local indigenes; rather the global-local dynamic of knowledge systems should be embedded and contextualized in the "local knowledge and practices" (Jackson 2014 , p. 36). The argument put forward here is that the demystification of research can, in due course, promote indigenous research using localised research tools and theoretical frameworks. Jackson (2014, p. 36) sums up the argument thus:

The purpose of indigenous research should be to give those weaker groups more voice to speak out, not just as subjects of research, but in formulating the purpose and use of such research, and greater agency to affect policies and practices that impact on their lives.

It must be noted that a number of us have already started to follow this path of teaching research using every day people's practices and experiences. That way, we have sought to explore ways of empowering marginalised voices in the education system and research in Africa, which is mostly based on Western education, and oftentimes using Eurocentric research models of teaching and conducting research. We thus concure with Banda and Banda (2017) that a more efficacious system is one in which Western-style education systems are embedded in IKS and and research. This would entail mainstreaming IKS and everyday people's practices and experiences to demystify research as illustrated and discussed in this paper. This means it is imperative to take into account the African cultural and social contexts under which research is being conducted. The Westernisation of research protocols and epistemologies, as well as the ritualization of research does not only add to mysticism associated with Eurocentric research, but it also adds to perceptions that only the elite or formally educated specialised people are eligible to do research.

\section{References}

Banda, Dennis. 2008. Education for All (EFA) and African Indigenous Knowledge Systems (AIKS). The Case of the Chewa People of Zambia. Herstellung, Germany: Lambert Academic Publishing.

Banda, Felix, and Dennis Banda. 2016. "Nyanja/Chewa Proverbs as Didactics: Recontextualising Indigenous Knowledge for Academic Writing." Studies in Tribes and Tribals 14(2): 80-91.

Banda, Felix, and Dennis Banda. 2017. "Everyday Experiences as Socio-cultural Co(n)texts for Effective Research Methods in Teaching and Learning in Institutions of Higher Learning in Africa." Scholarship of Teaching and Learning in the South 1 (1): 60-77.

Hoppers, Catherine A. Odora. 2004. Culture, Indigenous Knowledge and Development: The Role of the University. Occasional Paper No. 5. Johannesburg: Centre for Education Policy Development.

Islam, Rezaul, and Dennis Banda. 2011. "Cross-Cultural Social Research with Indigenous Knowledge (IK): Some Dilemmas and Lessons." Journal of Social Research \& Policy 2 (1): 67-82.

International Council for Science (ICSU) Study Group. 2002. Science, Traditional Knowledge and Sustainable Development. Series on Science for Sustainable Development No. 4. Paris: ICSU and UNESCO.

Jackson, Terence. 2014. "How can We Encourage Indigenous Research?” International Journal of Cross Cultural Management 14 (2): 135-137.

Kamanga, S. 1996. Nzeru Zakale. Lusaka: Longman.

Kambanda, S. 2004. Proverbs and the Socialisation of Young Rwandans. Unpublished Master's Thesis, University of the Western Cape, Bellville, South Africa. 